\title{
2 次因子分析における構成概念の平均值の比較
}

\author{
——ブランド価值の継時的比較を例にとって——
}

\author{
豊 田 秀 樹*, 福 中 公 輔** \\ 川端 一 光*, 片 平 秀 貴***
}

A Comparison between the Construct's Mean Values for Secondary Factor Analysis :

Successive Comparisons of Bland Value

Hideki ToyodA*, Kosuke FukUnakA**, Ikko Kawahashi** and Hotaka Katahira

In this study, a secondary factor analysis of multiple populations with a structured mean was applied to the independent, and mean values were decomposed into common and unique components. In this manner, a method for discovering the most effective model was proposed. In order to ensure the practical effectiveness of this method, the data of Brand Japan from 2004 to 2006 was analyzed. This data was composed of 1,000 brands and 15 variables. As a result, some models fitted to the data well in all variations of models, and the best model could be decided by interpreting meanings. This model was applied to the brand data, and factor scores were calculated for every construct. Characteristics of every brand were discovered by observing its movement.

Key words: secondary factor analysis, multiple populations, mean structure, structural equation modeling, Brand Japan.

キーワード：2 次因子分析，多母集団，平均構造，共分散構造分析，ブランドジャパン

\section{1. 問 題 - 目 的}

構成概念を測定するための尺度を作成する研究で は，まず当該特性值の高低が行動的相違に顕著に現れ るであろう観測変数を多数収集し, 次に収集された観 測変数に対する反応データを因子分析して，逆に構成 概念の概念的分類を行うことが多い. 例えば中山 (2005) は自己能力に対する学習観という構成概念を発

\footnotetext{
*早稲田大学文学学術院

(Waseda University)

干 $162-8644$ 新宿区戸山 1-2-4

**早稲田大学大学院

(Graduate School of Letters, Arts and Sciences,

Waseda University)

干 162-8644 新宿区戸山 1-2-4

***グローバルビジネスリサーチセンター

(Global Business Research Center)

干 113-0033 文京区本郷 7-3-1 東京大学産学連携プ ラザ 5 階
}

音方略・体制化方略というより低次の 2 つの構成概念 で定義しているし，犬塚（2002）では読解方略の構造 として, 部分理解方略・内容学習方略・理解深化方略 という 3 つの構成概念を説明する高次の概念として, 方略使用傾向を想定している.また山森（2003）では 中学校に㧍ける学習評価に扔いて, 関心・意欲・態度 という 3 つの下位概念を 1 つの高次因子として統合し ている．この他にも藤井（1998）は大学生における不 安感を下位 3 尺度（日常生活不安・評価不安・大学不 適応）で, 森ら（1994）は不合理な信念を 5 つの下位 尺度（自己期待 - 依存・論理的非難・問題回避 - 無力 感) でそれぞれ定義している．このように心理学の研 究では, しばしば基本となる構成概念とそこから派生 した下位領域としての構成概念を同時に扱う。このよ うな研究状況で効果的に用いられる分析手法に構造方 程式モデリング (structural equation modeling, 狩 野・三浦，2002，豊田，1998）における 2 次因子分析 
（Bollen, 1989）がある.

ただし関心の対象となっている構成概念の階層構造 を明らかにしても，この段階では構成概念と行動特性 との関係は記述されない. 研究の次なる段階として, 性別・立場・実験的操作・年齢・年度などの離散的変 数が，特性值の分布（特に平均值）に与える影響を調 べることへと移行していくことが重要である．基本と なる構成概念とそこから派生した下位領域としての構 成概念の関係と, 離散変数との関係を同時に分析する ための数理モデルとして因子の平均を構造化（Sörbom, 1982）した多母集団の 2 次因子分析モデルがあ る. 基本となる構成概念を 2 次因子に指定し，下位領 域としての構成概念を 1 次因子に指定し, 離散変数を 異なった母集団に指定し，因子の平均構造を分析すれ ば, 離散変数が構成概念に与える影響を効果的に考察 できるはずである.しかしこれまで平均を構造化した 多母集団の 2 次因子分析モデルは, このような動機で は，ほとんど利用されてこなかった。適用場面は多い はずであり，ユーザーフレンドリーなソフトウェアが 提供されているにも係わらず利用されないのは, 標準 的なソフトウェアの出力だけでは解釈しにくいためで ある。

本研究の目的は, 基本となる構成概念とそこから派 生した下位領域としての構成概念との関係, 及びそれ らと離散変数との関係とを, 主に平均值に着目して同 時に分析する際に, 平均を構造化した多母集団の 2 次 因子分析の結果を効果的に利用するために有効なモデ ルのバリエーションを整理・分類し, 有効性を考察す ることである.

\section{2. 方}

\section{法}

2 次因子分析では, 2 次因子の数に限定はないが，こ こでは基本となる構成概念を想定しているので 2 次因 子の数を 1 つとして $f_{0}^{(g)}$ と表記し

$$
f_{0}^{(g)}=\alpha_{0}^{(g)}+\zeta^{(g)}
$$

と分解する.ここで $\alpha_{0}^{(g)}$ は 2 次因子の平均であり， $\zeta^{(g)}$ は集団内の観測対象の違いを表現する平均 0 の確率変 数である.ここで肩に乗った ${ }^{(g)}$ は $g$ 番目の離散的状態 を表現する添え字とする $(g=1, \cdots, G)$. $\zeta^{(g)}$ の分散を $\phi^{(g)}$ とすると 2 次因子の平均と分散は

$$
E\left[f_{0}^{(g)}\right]=\alpha_{0}^{(g)}, \quad V\left[f_{0}^{(g)}\right]=\phi^{(g)}
$$

となる。

基本となる構成概念である 2 次因子 $f_{0}^{(g)}$ は, そこか ら派生した下位領域の構成概念である 1 次因子 $\boldsymbol{f}^{(g)}$ に

$$
\boldsymbol{f}^{(g)}=\boldsymbol{\alpha}^{(g)}+\boldsymbol{a} f_{0}^{(g)}+\boldsymbol{\epsilon}^{(g)}
$$

という影響を与える。 $\alpha^{(g)}$ は $\boldsymbol{f}^{(g)}$ の切片であり, $a$ は因 子パタンベクトルである. $\boldsymbol{\epsilon}^{(g)}$ は誤差ではなく, 基本と なる構成概念では説明されない下位領域の各側面の独 自性を表現している， $\boldsymbol{\epsilon}^{(g)}$ の要素は互いに無相関を仮 定することが多く, $i$ 番目の要素の分散を $\phi_{i}^{(g)}$ と表記 する.

$i$ 番目の下位領域の構成概念 $f_{i}^{(g)}(i=1, \cdots, m)$ の平 均は

$$
E\left[f_{i}^{(g)}\right]=\alpha_{i}^{(g)}+a_{i} \alpha_{0}^{(g)}
$$

である。ここで重要なことは母集団 $g$ における構成概 念 $i$ の平均値は,

(1) 基本となる構成概念の平均の影響 $a_{i} \alpha_{0}^{(g)}$ と

(2) 構成概念 $i$ の独自の平均 $\alpha_{i}^{(g)}$

の和で表現されることである.

たとえば下位の構成概念 $i$ に関して女性の平均值の 方が男性より高く

$$
E\left[f_{i}^{\text {(女) }}\right]>E\left[f_{i}^{\text {(男) }}\right]
$$

であったとしても，それは基本となる構成概念におい て女性の平均值が高いのか, 下位の領域の独自性の平 均が高いのか, あるいはその両方なのかという 3 通り の可能性があり, それらの相違の解釈は心理学的に重 要なことが多いであろう. 場合によっては基本となる 構成概念の平均か, 下位の領域の独自性の平均は, 男 性のほうが高いこともあり得る。

構成概念の平均值の差は, 長さや重さのようにその 差自体に意味づけすることが難しいから, 分散の大き さとの比較をする必要がある。 $f_{i}^{(g)}$ の分散は

$$
V\left[f_{i}^{(g)}\right]=a_{i}^{2} \phi^{(g)}+\phi_{i}^{(g)}
$$

となる.ここで重要なことは母集団 $g$ における構成概 念 $i$ の分散も，また

(1) 基本となる構成概念に基づく分散成分 $a_{i}^{2} \phi^{(g)}$ と

(2) 構成概念 $i$ の独自の分散成分 $\psi_{i}^{(g)}$

の和で表現されているということである.

下位領域の構成概念は, 群間で共通した観測変数に

$$
\boldsymbol{x}^{(g)}=\beta+\boldsymbol{A} \boldsymbol{f}^{(g)}+\boldsymbol{e}^{(g)}
$$


という影響を与える. $\beta$ は $\boldsymbol{x}^{(g)}$ の切片であり，A は因 子パ夕ン行列である. $e^{(g)}$ は, 誤差変数である. $e^{(g)}$ の 要素は互いに無相関で, $i$ 番目の要素の分散を $\delta_{i}^{(g)}$ と 表記する。

SEM において多母集団解析を行い，構成概念の比 較をするためには以下の 4 つの仮定が導入されること が多い（豊田，1988）。

1. 各構成概念の平均と分散を，1 つの集団に限って 固定する.ここでは $\alpha_{0}^{(1)}=0, \alpha_{i}^{(1)}=0, \phi^{(1)}=1, \psi_{i}^{(g)}$ =1 とする.

2. 観測変数の切片は群間で等しい. $\beta$ には添え字 ${ }^{(g)}$ が着かない.

3. 因子パタンは群間で等しい. $\boldsymbol{a}$ と $\boldsymbol{A}$ には添え字 (g) が着かない.

4. 誤差分散は群間で等しい. $\delta_{i}^{(1)}=\delta_{i}^{(2)}=\cdots=\zeta_{i}^{(G)}$

1 番目, 2 番目がモデルを識別させるための仮定であ り, 適合度には関係しない. 3 番目の仮定は測定不変の 仮定であり，これを仮定することは構成概念の意味が 群間で等しいことを意味する. 4 番目の仮定は, 観測変 数の測定誤差が群間で不変であるということを意味す る. 識別のための仮定ではないから, 群間での構成概 念の意味や誤差の大きさが異なっていれば適合は下 がってしまうが，本論文では上記 4 つを全て仮定して 分析を進める. 以上は 2 次因子モデルに限らない, 多 母集団の平均構造モデルに関する仮定である.

分散に関する選択肢

2 次因子モデルに特有のモデル化に際しては, 分散 の制約に関して 2 種類の選択肢が考えられる.

共通分散 $\phi^{(1)}=\phi^{(2)}=\cdots=\phi^{(G)}$ と制約するか, 自由に推 定して制約を解放するか.

独自分散 $\phi_{i}^{(1)}=\psi_{i}^{(2)}=\cdots=\psi_{i}^{(G)}$ と制約するか, 自由に推 定して制約を解放するか.

実際には $i$ の違いによって, 制約を固定するか推定す るかを決められるし，gの違いによっても制約を固定 するか推定するかを決められるので, 本来, 細かいバ リエーションは無数に生じる. しかしそれでは煩雑さ が増してしまうので，ここでは 2 種類の選択肢を組み 合わせて「 $\phi$ 固定 $\phi$ 固定」「 $\phi$ 固定 $\phi$ 推定」「 $\phi$ 推定 $\psi$ 固定」「申推定 $\phi$ 推定」という 4 通りの制約でモデルの 考察を進める.

切片に関する選択肢

更に構成概念の切片に関しても，2 種類の選択肢が
考えられる。

共通切片 $\alpha_{0}^{(2)}=\alpha_{0}^{(3)}=\cdots=\alpha_{0}^{(G)}=0$ と制約するか, 自由に 推定して制約を解放するか.

独自切片 $\boldsymbol{\alpha}^{(2)}=\boldsymbol{\alpha}^{(3)}=\cdots=\boldsymbol{\alpha}^{(G)}=0$ と制約するか, 自由 に推定して制約を解放するか.

切片に関しても, 本来, 細かいバリエーションは無数 に生じるが, 同様に煩雑さが増してしまうので, ここ では 2 種類の選択肢を単純に組み合わせる. しかし共 通切片と独自切片は，両方とも0に制約してしまうと 構成概念の平均構造がなくなってしまうので，どちら かは残さねばならない.したがって構成概念の切片に 関しては 3 通りの制約でモデルの考察を進める. 以上 より, 分散 4 通り, 切片 3 通りの制約を組み合わせる と 12 通りのモデルが構成されることになる.

\section{1. 分析データ}

本研究では, 年度という離散変数が構成概念の平均 值に及ぼす影響を考察する。また年度による構成概念 の平均值の変化を考察した研究として鈴木 (2004) が 挙げられるが, 鈴木（2004）では 1 次因子の平均のみ を扱うのに対して, 本研究では高次因子をモデル中に 表現し, その因子平均の変動についても考察する点で 区別される. 従って高次因子分析モデルで作成された 調查を離散変数ごとに実施したデー夕を用意しておく 必要がある。

日経 BP コンサルティングによるブランドジャパン (日経 BP コンサルティング，2002) は，ブランド力を 企業評価の為の 1 つの指標とするべく 2001 年から 2006 年現在に至るまで, 毎年 1 回ずつ実施されている 調査プロジェクトである.

ブランド力とは, 顧客に対して提供される製品や サービスの価值を増加させたり減少させたりするとい う意味でのブランドの資産価值のことであり，例えば Aaker (1996) はブランドカを “知覚品質” “ロイヤル ティー” “ブランド認知”の積（体積）として説明して いる.

日経 BP コンサルティングによるブランドジャパン は，構造方程式モデリングを利用した 2 次因子分析モ デルとして表現されている. 図 1 はこの 2 次因子分析 モデルのパス図（豊田, 1998, 狩野・三浦, 2002）で ある。パス図中の楕円は構成概念を表現しており, 左 端にある “総合力”がその年のブランドの総合的な実 


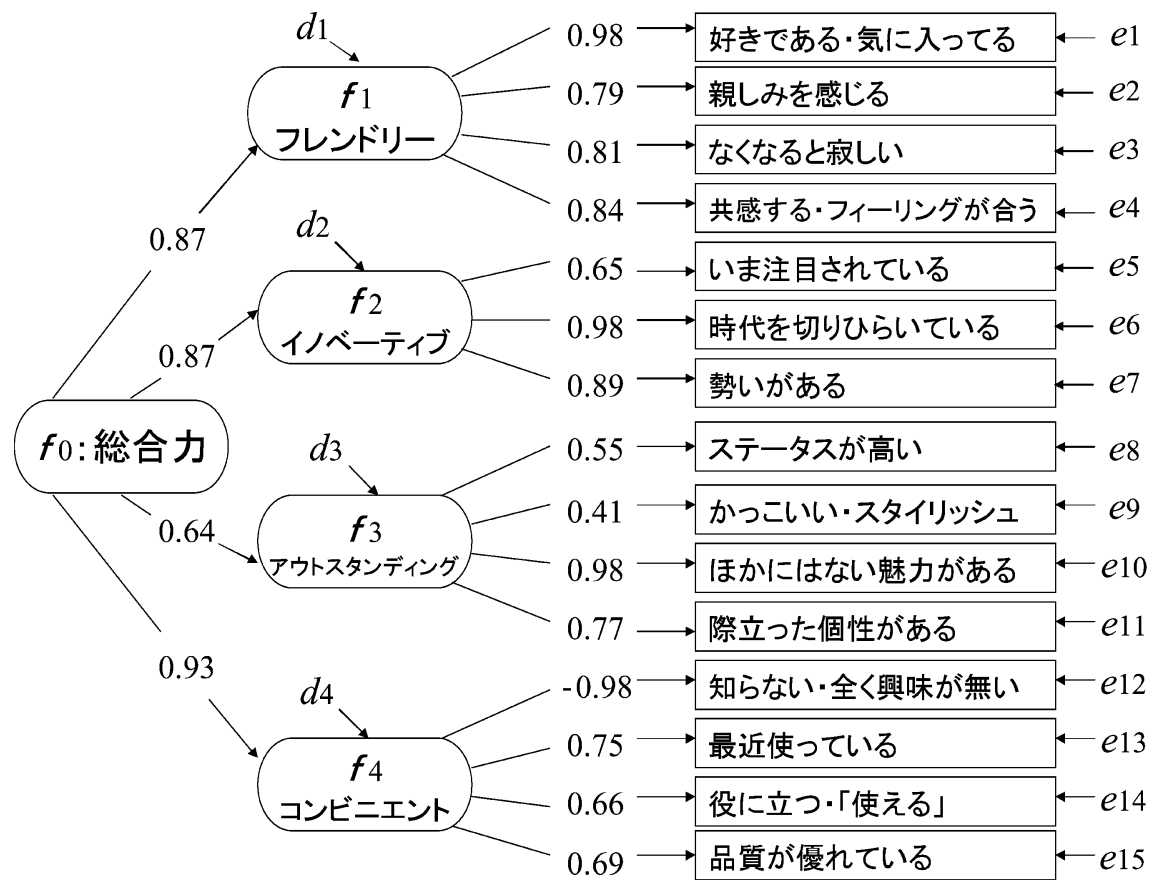

図 1. ブランドジャパン 2006 における 2 次因子分析モデルのパス図

力を表現している. パス図の中央の4つの楕円 “フレン ドリー”“イノベーティブ”“アウトスタンディング” “コンビニエント”は総合指標だけでは捕らえきれな いブランドの諸側面の構成概念を表現している.さら に，それぞれの諸側面は，右側の四角で囲まれた複数 の観測変数によって測定されている.

ブランドジャパン 2001, 2002, 2003 では郵送・Web 調査の両方法によって標本抽出をしていたが，2004， 2005，2006 では有意抽出による Web 調査のみに限定 している.またブランドジャパン 2004 以降の調査では 有意抽出による Web 調査を採用するにあたって予想 される回答の歪曲を, 2003 年度で実施された郵送調查 (無作為抽出)の回答を利用した傾向スコアウェイティ ング法（Rosenbaum \& Rubin, 1983）を用いることで 補正している.

ブランドジャパンには調查対象を消費者としたコン シューマー市場 (BtoC) 編と, ビジネスパーソンを対 象にしたビジネス市場 (BtoB) 編の区別がある，BtoC では調查対象となるブランドは 1,000 の企業・商品ブ ランドであり, BtoBでは 500 の企業ブランドである. 本研究では一般消費者に対して実施された BtoC 調査 を分析対象とする。
本研究では, 特に 2004, 2005, 2006 で得られたデー 夕をもとに議論を進めることにする.これは 2003 年度 以前では，標本の抽出法や尺度構成のための統計モデ ルが一意に定まって抢らず，そのことが結果に系統的 なバイアスとして混入することを避ける為である。

調査期間 2004 年度調查では 2003 年 11 月 14 日 ～ 2003 年 11 月 21 日までの期間で, 2005 年度調查では 2004 年 11 月 4 日〜2004 年 11 月 24 日の期間で， 2006 年度調查では 2005 年 11 月 7 日から 11 月 28 日までの 期間で調査が実施された。また 2002 年度郵送調査は, 2001 年 11 月 10 日〜 2002 年 2 月 7 日の期間で, 2003 年度郵送調查は 2002 年 11 月 15 日～2003 年 12 月 16 日の期間で調査が実施された。

調査形態 Webによる有意抽出調査により実施さ れた。調査実施中にブランドジャパンの Web サイト にアクセスした 18 歳以上の男女ならば, 誰でも回答で きるオープン形態をとった。

調査票 20 ブランドを 1 組とし 50 組に分け（従っ て全 1,000 ブランド), 回答者 1 人に対して無作為に 1 組の評価を求める．また主要な設問は両年で同じもの を用いている. 各設問は 2 值変数としてコーディング される，ただし最初の項目で知らないと答えた被験者 
に関しては, 以後の項目には回答させていない.

有効回答数 有効回答数は2004年度において 25,340, 2005 年度において 23,990, 2006 年度において 27,560であった. 傾向スコアの算出に用いられる 2002 ・2003 年度の郵送調査は全国の住民台帳から選択 された 100 地域から, 50 世帯ずつ無作為抽出し, 選ば れた各世帯に 2 つ調査票を郵送することで行われた。 また調查票は各世帯の 18 以上の男女を対象としてい る. 2002 年度郵送調査の有効回答数は 4,587, 回収率は 45.9\% であった.また 2003 年度の郵送調査の有効回答 数は 2,390 , 回収率は $23.9 \%$ であった。

\section{3. モデル選択と平均構造}

\section{1. 結果}

まず，被調查者ごとに「YES/NO」で得られた 2 值 変数を, オブザベーションをブランドとする形式とな るように集計を行った. 各ブランドの変数ごとに $\lceil\mathrm{YES}$ と回答した人数を算出し, その変数に回答した 全被調查者数で除することによって各ブランドのその 変数における点数を求めている.

次に 2004 年度から 2006 年度までのブランドジャパ ンの調查結果を用いて平均構造の入った多母集団の 2 次因子分析を行った。このとき, 各年度を 1 つの母集 団とするため, 全部で 3 群となり, 各群はそれぞれ 1,000 のオブザベーションであった.これは毎年 1,000 のブランドを選択して調査を実施していたためであ る. 分析には 3 年分で標準化したデータを用い, 推定 には最小 2 乗法を利用した。 なお, ソフトウェアには $\mathrm{EQS}^{1}$ を使用した。

基本的制約条件として, 初年度 (2004 年度) の 1 次 因子と 2 次因子の平均を 0 , 分散を 1 に固定し, 観測変 数の切片および因子パタン，そして誤差分散を群間で 等しいものとした. また, 本研究における特殊制約条 件として, 群間における構成概念の分散の等值制約と 2 年目（2005 年度）および 3 年目（2006 年度）の構成 概念の切片に 0 制約を置いた。ここで, 0 制約とは推定 すべき母数を 0 に固定することを意味する.

モデルはこの特殊制約条件の有無の組合せだけ構築 するが, 切片に関する制約に関して, 1 次因子と 2 次因 子の両方を 0 に固定する場合を除くので, その数は全

1 構造方程式モデリングのソフトウェア. 詳しくは http://www.mvsoft.com/を参照.
表 1. 構成概念の切片と分散の制約に関する組合せ の全モデルの適合度指標

\begin{tabular}{lllllll}
\hline & $\chi^{2}$ 值 & df & GFI & AGFI & CFI & RMSEA \\
\hline$\alpha_{0}$ 推定 $\alpha$ 推定 & & & & & & \\
$\phi$ 固定 $\phi$ 固定 & 7,940 & 346 & 0.916 & 0.907 & 0.895 & 0.086 \\
$\phi$ 固定 $\phi$ 推定 & 7,722 & 334 & 0.918 & 0.906 & 0.898 & 0.086 \\
$\phi$ 推定 $\phi$ 固定 & 7,554 & 343 & 0.920 & 0.911 & 0.900 & 0.084 \\
$\phi$ 推定 $\psi$ 推定 & 7,469 & 331 & 0.921 & 0.909 & 0.901 & 0.085 \\
\hline$\alpha_{0}$ 固定 $\alpha$ 推定 & & & & & & \\
$\phi$ 固定 $\phi$ 固定 & 7,940 & 348 & 0.916 & 0.907 & 0.895 & 0.085 \\
$\phi$ 固定 $\psi$ 推定 & 7,722 & 336 & 0.918 & 0.906 & 0.898 & 0.086 \\
$\phi$ 推定 $\phi$ 固定 & 7,554 & 345 & 0.920 & 0.911 & 0.900 & 0.083 \\
$\phi$ 推定 $\phi$ 推定 & 7,469 & 333 & 0.921 & 0.909 & 0.901 & 0.085 \\
\hline$\alpha_{0}$ 推定 $\alpha$ 固定 & & & & & & \\
$\phi$ 固定 $\phi$ 固定 & 7,943 & 354 & 0.916 & 0.907 & 0.895 & 0.085 \\
$\phi$ 固定 $\phi$ 推定 & 7,725 & 342 & 0.918 & 0.906 & 0.898 & 0.085 \\
$\phi$ 推定 $\phi$ 固定 & 7,557 & 351 & 0.920 & 0.911 & 0.900 & 0.083 \\
$\phi$ 推定 $\phi$ 推定 & 7,472 & 339 & 0.921 & 0.909 & 0.901 & 0.084 \\
\hline
\end{tabular}

$\alpha_{0}: 2$ 次因子の切片 (共通切片), $\alpha: 1$ 次因子の切片 (独自切片), $\phi: 2$ 次因子の分散 (共通分散), $\phi: 1$ 次 因子の分散（独自分散）

部で 12 通りであった.この全 12 通りの分析結果の適 合度指標を表 1 に示す. 表 1 よりすべてのモデルにお いて, GFI・AGFI ともに 0.9 を超えており，比較的良 好な適合を示していることがわかった。しかしその中 でも，切片の制約に関する 3 通りの組合せのそれぞれ において,「申推定 $\phi$ 固定」のモデルの RMSEA が最 小となっていた。 そこで本研究では, 以後, この 3 通 りのモデルに注目することにした。

次にこの 3 つのモデルについて, 経年における 2 次 因子と 1 次因子の平均值の推移を各構成概念ごとに図 2 から図 5 に示す. 図 2 は 3 つのモデルにおける 2 次 因子の平均值の推移を, 図 3 から図 5 は各モデルごと に 1 次因子それぞれの平均值の推移を示している. た だし図 3 から図 5 では, 1 次因子の平均值 (1 次因子総 平均) $E\left[f_{i}^{(g)}\right]$ を分解した要素である, (1) 2 次因子から の平均の影響 (共通平均) $a_{i} \alpha_{0}^{(g)}$ と (2) 1 次因子の各構 成概念 $i$ の独自の平均 (独自平均) $\alpha_{i}^{(g)}$ およびそれぞれ の標準偏差も同時に示した. なお, 本研究では, 2 次因 子 (基本となる構成概念) $f_{0}$ は “総合力”, 1 次因子 (下位領域の構成概念) $f_{1}$ は “フレンドリー (親しみ)”, $f_{2}$ は“イノベーティブ (革新)”, $f_{3}$ は “アウトスタン ディング (卓越)”, $f_{4}$ は “コンビニエント (便利)”を それぞれ表している。 

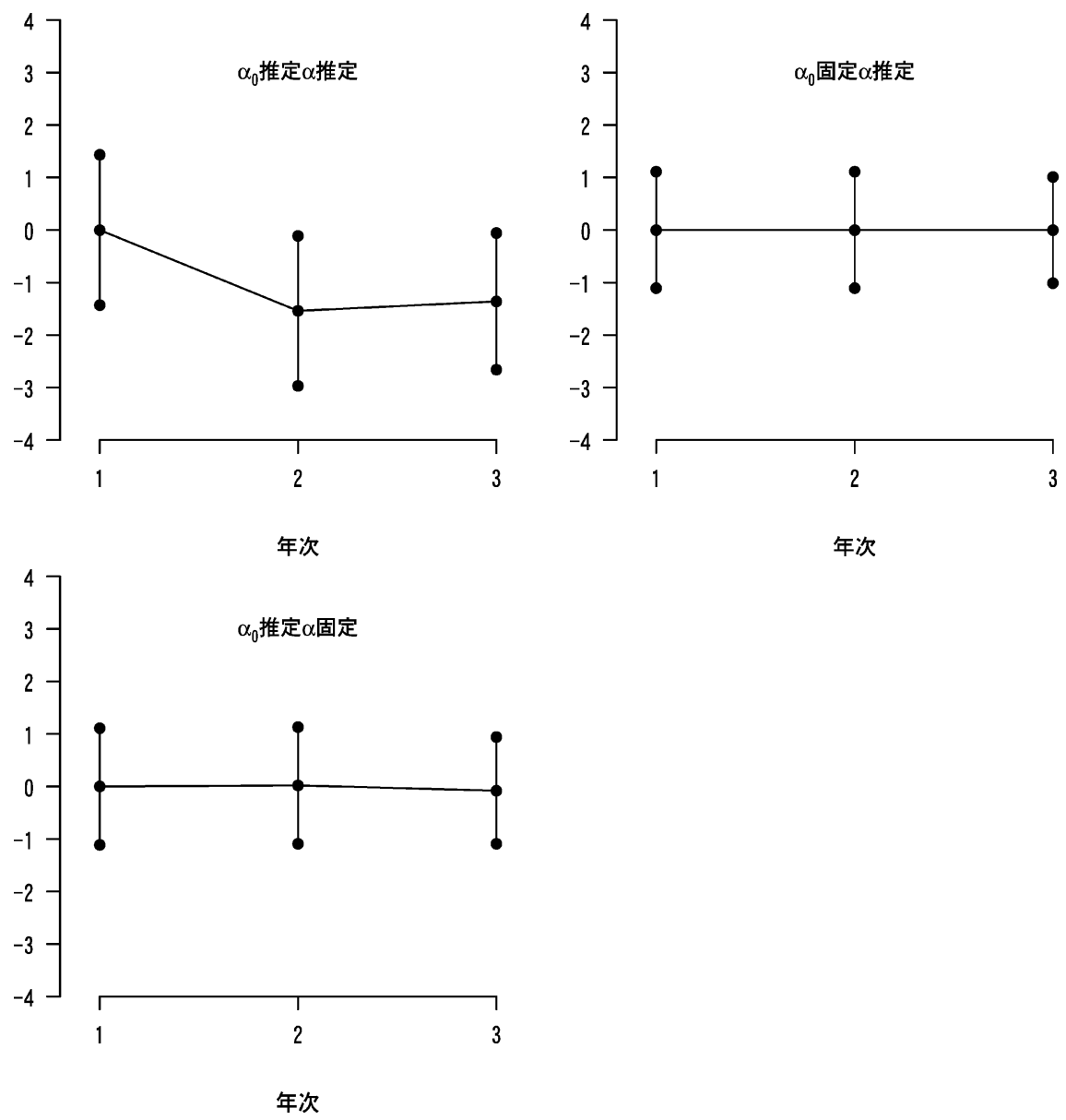

図 2. 3 つのモデルにおける 2 次因子 (総合力) の平均值の推移. 左上が $\left\lceil\alpha_{0}\right.$ 推定 $\alpha$ 推定 $\phi$ 推定 $\phi$ 固定」 モデル, 右上が $\left\lceil\alpha_{0}\right.$ 固定 $\alpha$ 推定 $\phi$ 推定 $\phi$ 固定」モデル, 左下が $\left\lceil\alpha_{0}\right.$ 推定 $\alpha$ 固定 $\phi$ 推定 $\phi$ 固定」モ デル

図 2 より,「 $\alpha_{0}$ 推定 $\alpha$ 推定」モデルの 1 年目から 2 年 目にかけての平均值は下降しているが， 2 年目から 3 年目にかけてはほとんど変化していないことがわかっ た.また，「 $\alpha_{0}$ 固定 $\alpha$ 推定」モデルと「 $\alpha_{0}$ 推定 $\alpha$ 固定」 モデルに関しては平均値にほとんど変化は見られな かった.

一方図 3 では, 「 $\alpha_{0}$ 推定 $\alpha$ 推定」モデルのすべての 1 次因子において, 1 次因子総平均に変化は見られな かったが, 独自因子は正の方向に, 共通平均は負の方 向に変化していた. 図 4 扔よび図 5 では, $「 \alpha_{0}$ 固定 $\alpha$ 推 定」モデルと「 $\alpha_{0}$ 推定 $\alpha$ 固定」モデルにおいて, 3 種 類の平均值はともに 3 年間で変化が見られなかった。

\section{2. 考察}

$\left\lceil\alpha_{0}\right.$ 推定 $\alpha$ 推定 $\phi$ 推定 $\phi$ 固定」モデル, $「 \alpha_{0}$ 固定 $\alpha$ 推 定 $\phi$ 推定 $\phi$ 固定」モデル, $「 \alpha_{0}$ 推定 $\alpha$ 固定 $\phi$ 推定 $\phi$ 固 定」モデルの 3 つのモデルについて考察を行う。これ ら 3 モデルは, デー夕の当てはまりが比較的良好であ り, 適合度指標だけからでは最終的に採用すべきモデ ルを決定することはできない. そこで, 各モデルを詳 細に検討し，意味的な解釈を行った上で最終的なモデ ルを決定する必要がある。

まず, $「 \alpha_{0}$ 推定 $\alpha$ 推定 $\phi$ 推定 $\phi$ 固定」モデルに関し て, 図 3 より, 1 次因子総平均の変化のなさは, 独自平 均と共通平均が相補的に振舞い, その結果相殺されあ うことによって起こったことが分かった.しかし,2004 

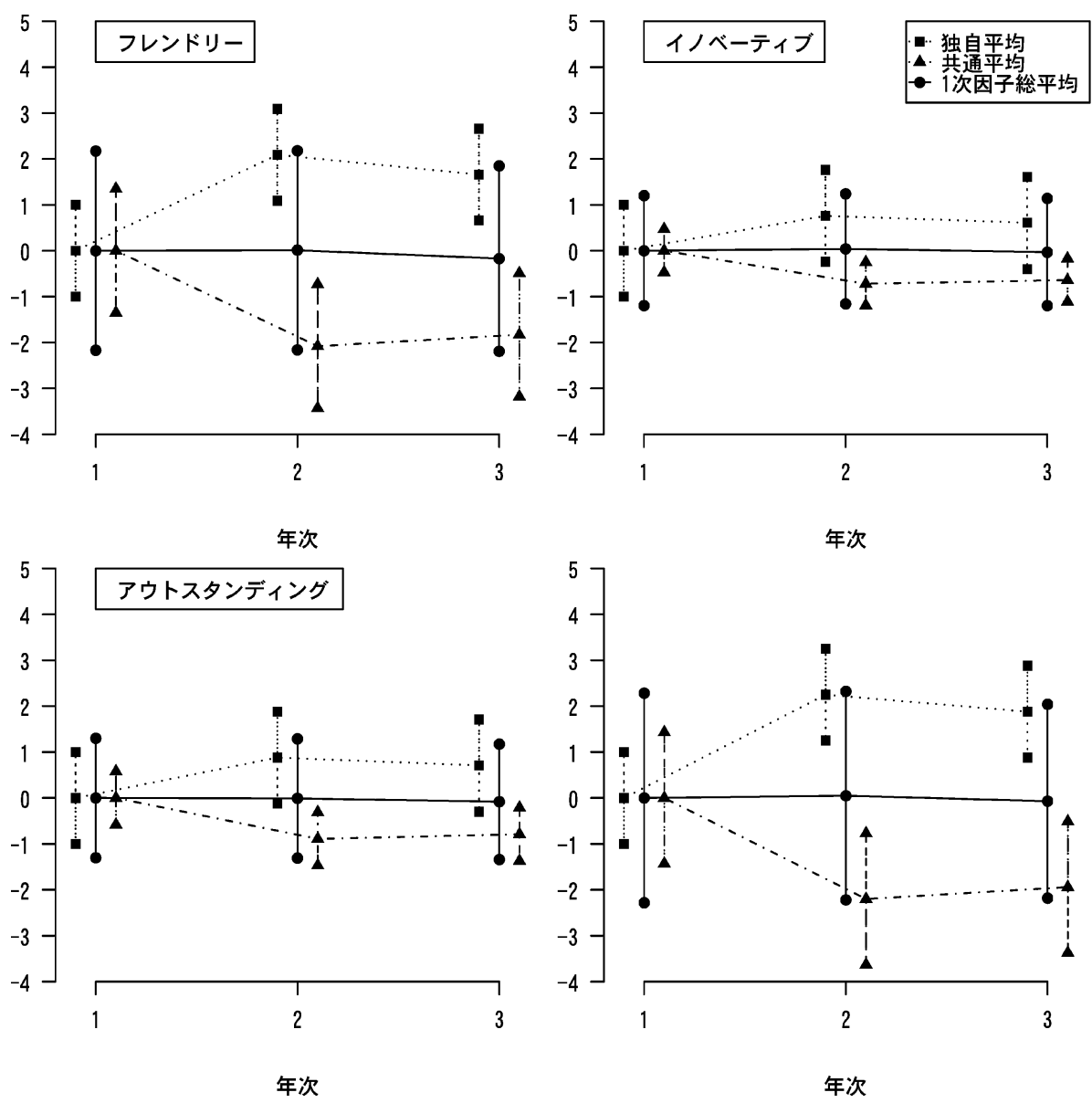

図 3. $\left\lceil\alpha_{0}\right.$ 推定 $\alpha$ 推定 $\phi$ 推定 $\phi$ 固定」モデルにおける 4 つの 1 次因子の平均值の推移

年度から 2006 年度の 3 年間のブランドジャパンの調 査は，その調査状況が等しくなるように，細心の注意 を払って実施されており，各年度ごとに行われた分析 結果の安定性の度合いから見ても，すべての 1 次因子 においてこのような極端な結果になるとは考えにく い.したがって，図 3 のような結果は，不適切な制約 による不自然な結果（artifact）であると考えられる. よって, 本研究ではこのモデルは不採用とすることに した.

次に $\left\lceil\alpha_{0}\right.$ 固定 $\alpha$ 推定 $\phi$ 推定 $\phi$ 固定」モデルと「 $\alpha_{0}$ 推 定 $\alpha$ 固定 $\phi$ 推定 $\phi$ 固定」モデルに関してであるが, 本 研究の目的は構成概念の平均構造の変化を観察するこ とであり, 本研究のようなタイプの 2 次因子分析の場 合，2 次因子よりも 4 つの 1 次因子に注目した方がよ り情報量の多い知見が得られる.したがって, 2 次因子
の平均を推定し 1 次因子の平均を固定したモデルより も，その逆のモデルを採用した方が良いと考えられる。 そこで最終的に，「 $\alpha_{0}$ 固定 $\alpha$ 推定 $\phi$ 推定 $\phi$ 固定」モデ ルを採用することにした。

\section{4. 事}

例

\section{1. 結果}

最終的に採用された $\left\lceil\alpha_{0}\right.$ 固定 $\alpha$ 推定 $\phi$ 推定 $\phi$ 固定」 モデルのパス係数を表 2 に示す. 項目 $a\lceil$ 知らない・全 く興味がない」のみ因子パタンが負の值を示しており, それ以外はすべて正の值であった。この結果は従来の ブランドジャパンの結果と整合性を保持するもので あった。

次に,この因子パタンと平均構造の結果を用いて, 各 

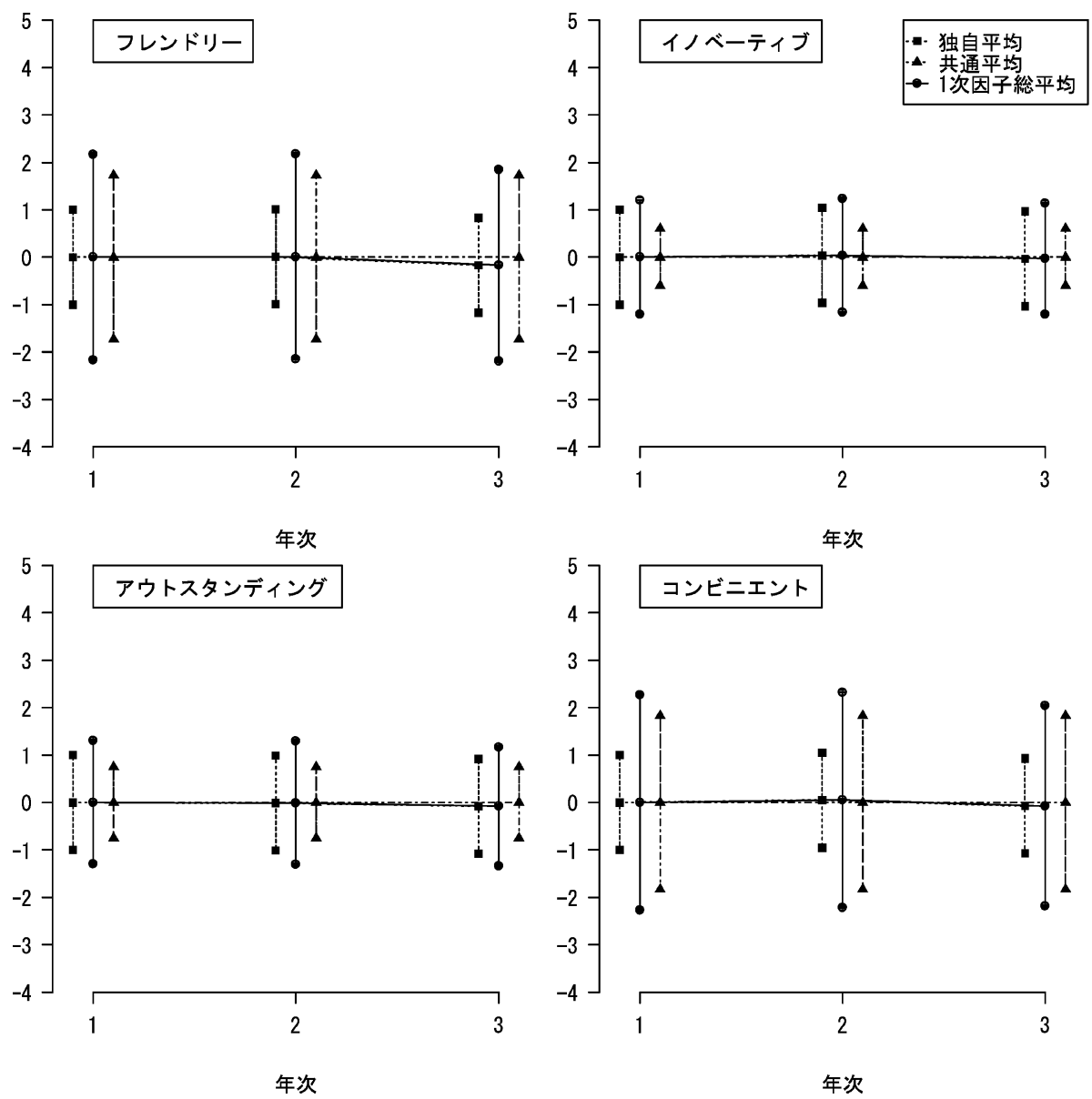

図 4. $\left\lceil\alpha_{0}\right.$ 固定 $\alpha$ 推定 $\phi$ 推定 $\phi$ 固定」モデルにおける 4 つの 1 次因子の平均值の推移

ブランドごとに因子平均に基づくスコア $\boldsymbol{F}$ を算出し た。計算には以下の式を用いた。

$$
\begin{gathered}
\boldsymbol{F}_{i}^{(g)}=\boldsymbol{M}_{i}^{(g)}+\boldsymbol{Z}^{(g)} \boldsymbol{W}_{k} \\
\boldsymbol{F}_{0}^{(g)}=\boldsymbol{F}_{i}^{(g)} \boldsymbol{W}_{i}
\end{gathered}
$$

ここで, $\boldsymbol{F}_{i}$ は 1 次因子のスコアを, $\boldsymbol{F}_{0}$ は 2 次因子の スコアを示している.また, $\boldsymbol{M}_{i}^{(g)}$ は各年度ごとの 1 次 因子の平均構造であり, $\boldsymbol{Z}^{(g)}$ は 3 年分で標準化した後 の年度ごとの観測変数の值であった.一方, $\boldsymbol{W}_{k}$ は 1 次 因子と観測変数間の重み行列（因子パタン行列）であ るが, 本研究でのモデルは測定不変の制約を置いてい るので, 添え字 $(g)$ は付かない. 同様に, $\boldsymbol{W}_{i}$ は 2 次因 子と 1 次因子間の重み行列である.

この式を用いて, 構成概念ごとに因子スコア $\boldsymbol{F}$ を計 算し, 経年によるブランドごとの推移を観察した。こ
のうち図 6 には, 特徵的な推移を示していた A ブラン ドと B ブランドの推移図を示す。図 6 の左図より, A ブランドはイノベーティブ因子と総合力因子が急激に 上昇しているが，それ以外の因子ではほぼ横ばいであ ることが分かった.また, 2005 年度と 2006 年度におい て，イノベーティブ因子のみ正の值となっていた。一 方, 右図より, B ブランドは総合力の下降が激しく, ま たそれ以外の 1 次因子も緩やかではあるが下降してい た。

\section{2. 考察}

A ブランドは株式売買に関係するブランドである. 現在, 株取引は, デイ・トレードを始めとした短期売 買が主流となりつつあり，これがある種のブームを引 き起こした．本来の『投資』という意味合いは薄れ，マ 

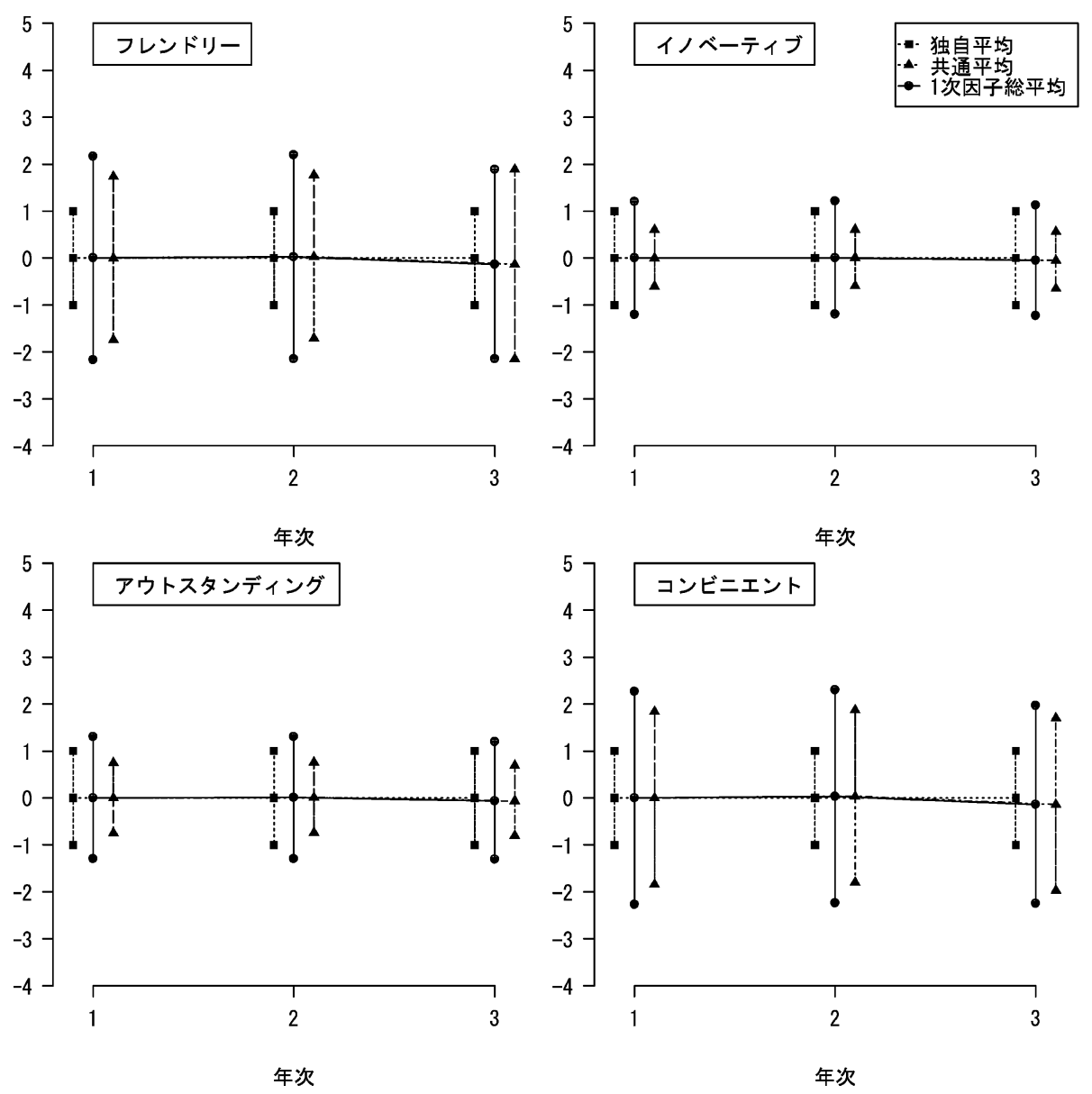

図 5. $\left\lceil\alpha_{0}\right.$ 推定 $\alpha$ 固定 $\phi$ 推定 $\phi$ 固定」モデルにおける 4 つの 1 次因子の平均值の推移

クロ経済学を熟知せずにゲーム感覚で取引に興じるト レーダーが次々に生まれた。このブームの発生にはイ ンターネットが何より貢献している.インターネット を利用することで，場所を選ばずリアルタイムに株取 引を行うことができるからだ。

図 6 の左図は, 近年ある種の社会現象にまでなった 株式売買の現状をよく反映している.A ブランドは株 式のオンライン取引において，このブランド独自の非 常に優秀な取引用ソフトウェアを提供していることで 有名であるが，これがそのブランドの革新的度合いを 表すイノベーティブ因子のスコアの上昇となって表れ ている.

その一方で, A ブランドの因子スコアはそのほとん どが負の值であった。これは $\mathrm{A}$ ブランドのイメージの 低さを反映している.しかし, 総合力因子が急激に上
昇していることにより，A ブランドのイメージは急速 に良くなってきていることがわかる．この総合力の変 化は, イノベーティブ因子の影響力が反映された結果 であり, 発展途上にあるブランドであると考えられる. 次に，Bブランドについて考察する，B ブランドは 日本における公共放送局であり，それゆえにかなりの 大手ブランドである.このことは, 図 6 の右図より, 因 子スコアはほとんど正の值で, かつ初年度 (2004 年度) の総合力因子のスコアが大きな值であることからわか る.しかしこのブランドは, 近年相次ぐ不祥事を起こ した。そのため，顧客の信頼を失い，ブランド価值は 暴落した. それが総合力因子のスコアの急落につな がっているのであろう.

このブランドは不祥事の後, 顧客の信頼を回復しよ うと様々な試みを行ってきた.しかし，4つの下位因子 
のスコアも緩やかに下降していることから，その試み は成功しているとは言いがたい. 1 度失䜃したブラン ドの信頼を回復するということは非常に難しいという

表 2. 因子および観測変数の内容と因子パタン

\begin{tabular}{|c|c|c|}
\hline & 内 容 & 係数 \\
\hline$f_{1}$ & フレンドリー（親しみ） & 1.730 \\
\hline$f_{2}$ & イノベーティブ（革新） & 0.602 \\
\hline$f_{3}$ & アウトスタンディング (卓越) & 0.745 \\
\hline$f_{4}$ & コンビニエント（便利） & 1.833 \\
\hline$a$ & 知らない・全く興味がない & -0.463 \\
\hline$b_{1}$ & 最近使っている & 0.341 \\
\hline$b_{2}$ & 好きである，気に入っている & 0.471 \\
\hline$c_{1}$ & 役に立つ,「使える」 & 0.303 \\
\hline$c_{2}$ & いま注目されている & 0.562 \\
\hline$c_{3}$ & ステータスが高い & 0.451 \\
\hline$c_{4}$ & 親しみを感じる & 0.367 \\
\hline$C_{5}$ & 時代を切りひらいている & 0.845 \\
\hline$C_{6}$ & かっこいい, スタイリッシュ & 0.353 \\
\hline$c_{7}$ & なくなると寂しい & 0.379 \\
\hline$c_{8}$ & 品質が優れている & 0.317 \\
\hline$c_{9}$ & 他にはない魅力がある & 0.836 \\
\hline$c_{10}$ & 共感する, フィーリングが合う & 0.404 \\
\hline$c_{11}$ & 勢いがある & 0.735 \\
\hline$c_{12}$ & 際立った個性がある & 0.613 \\
\hline
\end{tabular}

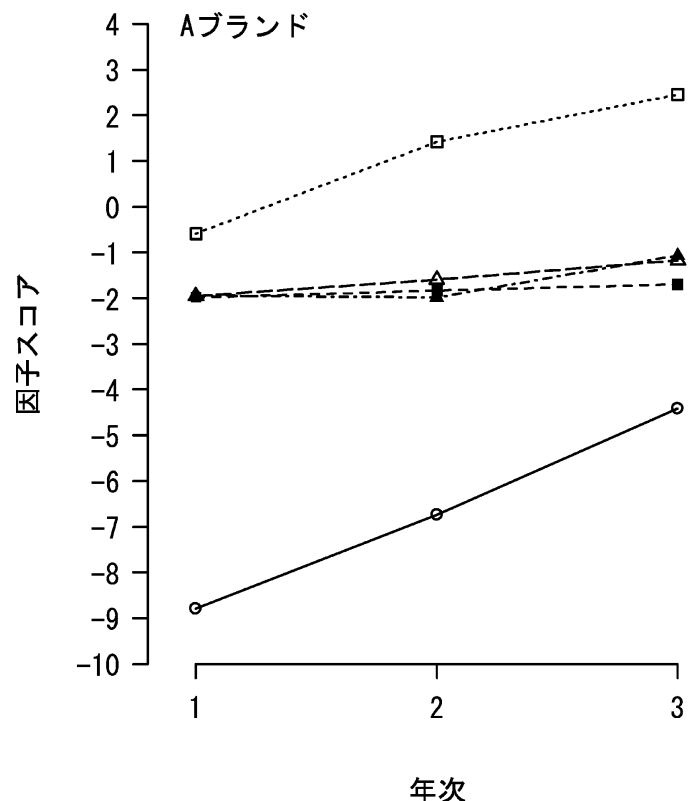

図 6. A ブランド（左図）と B ブランド（右図）の経年における因子スコアの推移
ことであろう。

\section{5. 総 合 的 考 察}

本研究では, 多母集団の平均構造を入れたモデルを 構成する際, 構成概念の切片と分散に制約を置くこと で 12 通りのモデルを考えた.そしてモデルの適合度と 意味的必然性から最終的な 1 つのモデルを決定するに 至った。

通常の平均構造を入れた 2 次因子分析では, 1 次因 子 2 次因子ともに切片を推定し, 母数を推定するのが 一般的である. しかし, 図 3 のように, 現実的に許容 しがたい結果が得られる場合もある.これは, 本研究 において提案した平均值の分解を行わない限り決して 気づくことのないモデルの不適合性である.ここに, 平 均構造に着目して, モデルの細かいバリエーションを 観察するメリットがある.

このように本研究の結果は, 心理学的研究をはじめ とした, その対象となっている現象の真の構造を適切 に反映したモデルを構築する際に非常に有効であると いえる。

また, 多くの場合, 現象や仮説を適切に反映したモ デルを構築するだけでは研究は終わらない. 研究の次 なる段階は，そのモデル構築に使用したデータセット

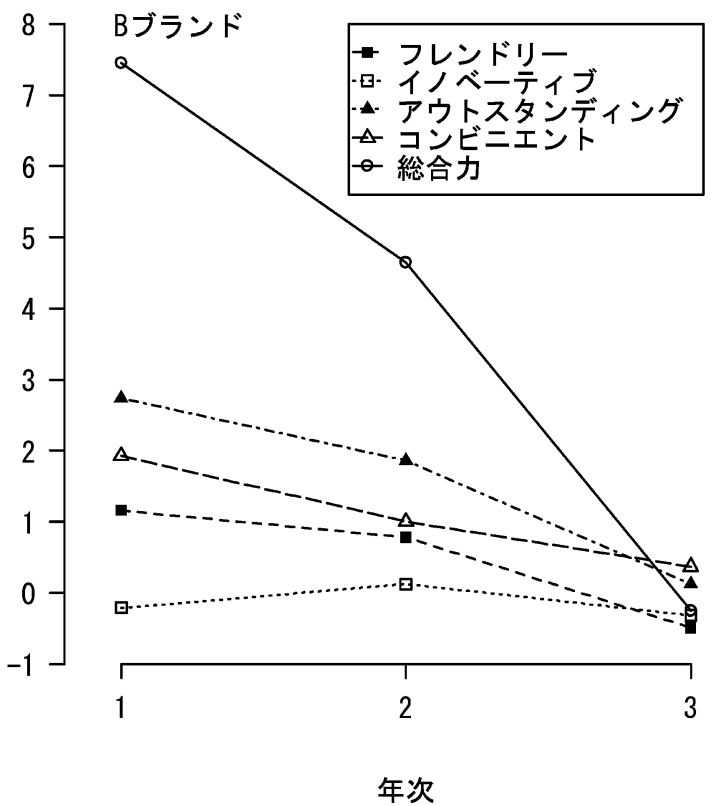


を構成している個体が，そのモデルの下でどのような 振る舞いをするかを明らかにすることである．本研究 の例で言えば，各ブランドの経年に伴う変動を調查す ることである.

ブランドというものは，それを開発した企業の状態 や株価の変動，そのときの経済状況や流行などと密接 な関わりがある。したがって，ブランド研究における 優れたモデルとは，個体に還元するときにはこれらの 社会的具体的要因を敏感に反映し，その一方で全体を 考察するときにはこれら具体的要因に対して頑健で安 定した結果を提供するものであるといえる.

これまでのブランドジャパンの結果と本研究の最終 モデルの結果である図 4 より, 本モデルは全体に対し て非常に安定した結果を提供しているといえる.また， 図 6 より，モデルを個体に還元したときは，その個体 とそれを取り巻く状況を適切に反映した結果を返して いる.したがって, 本研究の手法により構築されたモ デルは，まさしく上記の意味で優れたモデルであると いえる.

\section{参 考 文 献}

Aaker, D.A. (1996). Building Strong Brands. New York: Free Press. (アーカー, D. 陶山計 介, 小林 哲, 梅本春夫, 石垣智徳 (監訳) (1997). ブランド優位の戦略一顧客を創造する BI の開発 と実践一.ダイヤモンド社.)

Bollen, K.A. (1989). Structural Equations with Latent Variables. New York: Wiley.

藤井義久 (1998). 大学生活不安尺度の作成および信頼
性・妥当性の検討。心理学研究, $68,441-448$. 狩野 裕・三浦麻子 (2002).グラフィカル多変量解析 -AMOS, EQS, CALIS による目で見る共分散構 造分析一. 現代数学社.

森 治子・長谷川浩一・石隈利紀・嶋田洋徳・坂野雄 二 (1994). 不合理な信念測定尺 (JIBT-20) の開 発の試み。ヒューマンサイエンスリサーチ, VOL 3, 43-58.

中山 晃 (2005). 日本人大学生の英語学習における目 標思考性と学習館及び学習方略の関係のモデル化 とその検討. 教育心理学研究, 53, 322-330.

日経 BP コンサルティング (2002).ブランドジャパン 2002 総合報告書 [解説書]. 日経 BP コンサル ティング.

犬塚美輪（2002）。説明文に扔ける読解方略の構造. 教 育心理学研究, 50, 152-162.

Sörbom, D. (1982). Structural equation models with structured means. In Jöreskog, K.G., \& Wold, H. (Eds.) Systems under Indirect Observation, Part I (pp.183-195). Amsterdam : North-Holland.

Rosenbaum, P. \& Rubin, D. (1983). The central role of the propensity score in observational studies for causal effects. Biometrika, $\mathbf{7 0 .}$

鈴木督久（2002）. SEM による企業イメージのマネジ メント一平均構造・多母集団解析の応用一. 行動 計量学, 29, 174-181.

豊田秀樹（1998）。共分散構造分析［入門編］一構造方 程式モデリング一. 朝倉書店.

山森光陽 (2003).中学校英語科の観点別学習状況の評 価における関心・意欲・態度の評価の検討一多変 量一般化可能性理論を用いて一. 教育心理学研究, 51, 195-204.

（2006 年 12 月 2 日受付， 2007 年 1 月 16 日最終修正) 